\title{
Logic in religious and non-religious belief systems
}

\author{
Piotr Balcerowicz ${ }^{1,2}$
}

Received: 14 July 2017/ Accepted: 27 September 2017/Published online: 24 October 2017

(C) The Author(s) 2017. This article is an open access publication

\begin{abstract}
The paper first proposes a new definition of religion which features a novel four-layered element and which does not involve any circularity (as some definitions do); thereby, it allows to clearly distinguish the phenomenon of religion from certain other worldviews, in particular from certain political ideologies (a number of other definitions do not). Relying on the findings, the paper develops two structural conceptual models which serve to describe religious and non-religious belief systems. Further, the definition and the conceptual models allow to establish a clear criterion to distinguish pivotal structural differences between religious and non-religious belief systems. The criterion is based on the concept of two kinds of rationality: first-level and second-level rationalities. These will demonstrate to what degree religion can be a rational enterprise, and what role logic can play in it. The result is a clear-cut line in the structures of religious and certain consistent nonreligious belief systems (e.g. a scientific theory).
\end{abstract}

Keywords Logic - Worldviews - Two levels of rationality - Religion and science · Belief systems · Definition of religion

How can a religious person be rational, applying rules of logic, and at the same time irrational, making decisions based on faith? Are religious and non-religious belief systems structurally comparable, and if so, to what extent? The paper ${ }^{1}$ addresses the

\footnotetext{
1 This is an extended version of a paper read at the 2nd World Congress on Logic and Religion, University of Warsaw, 18-22 June, 2017.

Piotr Balcerowicz

piotrbalcerowicz1@gmail.com

1 Chair of South Asian Studies, Faculty of Oriental Studies, University of Warsaw, Krakowskie Przedmieście 26/28, 00-927 Warsaw, Poland

2 Present Address: ul. Niemcewicza 26/64, 02-306 Warsaw, Poland
} 
perennial question whether religious and non-religious belief systems are qualitatively different, by first formulating four defining features of every religion (i.e. a definition of religion), and then by proceeding towards demonstrating how logic can be used to derive theorems from a body of primitive notions in both kinds of belief systems. In this, religious belief system may appear to resemble a kind of deductive system with axioms (dogmas), theorems and rules of inference, however, only to a certain degree, as will be demonstrated. A key distinction between religious and non-religious belief systems will be introduced, based on two levels of rationality, and the degree to which logic can be applied, defined through the notion of modifiability, will be a touchstone.

Not every religion admits that it accepts logic as an instrument of inquiry into truth, but some do. In fact, there are a number of religions within which there are various strands out which some declaratively recognize rational enquiry as a vital tool to understand the contents of the divine message in whatever form, say, god's revelation or eternal truths promulgated by their religion. Within Christianity, for instance, we see can Catholic theologians more favourable disposed towards logic and reason than some of their Protestant counterparts for whom the gap between ratio and fides seems insurmountable and who deny that a religious person could develop faith or strengthen it through reason, argument and disputation. From such an incompatibilitist perspective, faith is not necessarily against reason, but it is certainly beyond it. Also within Islam we have a whole tradition of falsafa which developed Aristotelian philosophy and logic, represented by such distinguished thinkers as Ibn Sīnā (Avicenna), Ibn Rushd (Averroes) and many others, but also by their critics such as Al-Ghazālī. In Buddhism we find philosophers who, while being practicing monks, developed logic, such as Vasubandhu, Dignāga, Dharmakīrti and their Sautrāntika-Yogācāra school, but also other non-rational or even anti-rational tendencies which evolved into Zen Buddhism. Similar rational and anti-rational trends will be found in many other religions to a different degree. However, even such currents within a particular religion, or a particular religion in its mass, which reject the usefulness of logic and logic-based reasoning as a tool in the enquiry into revealed truths they accept, use logic practically in their argumentation, rhetorics and debate.

An essential step in an attempt to uncover a possible structural difference between religious and non-religious belief systems is to determine what religion is. Any formulation of a definition of religion should take into account a possibly comprehensive picture of various religious phenomena, including monotheistic and non-monotheistic (polytheist, henotheist etc.), theistic, atheistic, missionary, nonmissionary, tribal or so called 'world religions' (which is a misleading and prejudicial concept), etc., with various ontologies, metaphysics and moralities and systems of values. Most current and popular definitions of religion, such as "the experience of the sacred", "what people mean in religious discourse is what they ostensibly mean", etc., are problematic for various reasons which have been

\footnotetext{
${ }^{2}$ Developed by Otto (1917: 154)/(1926: 132), and adopted and popularized by Eliade (1949: esp. 'Introduction' and Chpt. 1).

${ }^{3}$ Kołakowski (1982: 9), following Lienhardt (1956: 322).
} 
discussed earlier. ${ }^{4}$ A new, more accurate definition should therefore be presented, which will be a point of departure for this paper. ${ }^{5}$

Any proper definition of religion should incorporate four essential components:

1. Doctrine, being a theoretical expression of a religious world-view (Weltanaschauung) and religious intuitions. The doctrine does not necessarily have to be formally codified in a body of dogmas, but it can be held as a loose, unsystematized and hardly structured system of beliefs, especially in premodern traditions.

2. Religious practice, or cult, being a practical expression of the doctrine and belief. This involves all actions, undertaken communally or individually, which are expressive of religious beliefs contained in the doctrine.

3. Community, being a social materialisation of the doctrine.

No religion is a personal affair, but it can only exist as a social phenomenon. Had the Buddha, for instance, not communicated his insight into the nature of the world, which he had gained at the awakening ('enlightenment') in Bodhgayā, to his former disciples and thereby established a community, or had Jesus not promulgated the divine revelation to his apostles and attracted some following of devotees, neither Buddhism nor Christianity would have come into existence, both being relegated to the subjective world of two individuals. The communal component includes both collective and individual aspects. The collective element is defined as individual-to-individual relation (interpersonal relations and actions of an individual vis-à-vis the cult and doctrine) and individual-to-group relation (relations and actions that link an individual to his/ her community). The individual aspect comprises one's own personal experience of what one perceives as something transcending his/her own human condition. Community always involves some kind of group stratification, i.e. hierarchy, which entails the idea of an individual or group with a 'privileged access' to the divine (the illuminati), either formally or functionally. Such hierarchy does not have to consist in a permanent, immutable structure of a religious community, but may be fluctuating, with blurred boundaries and adaptable to circumstances, with no permanently fixed higher positions, which can be occupied interchangeably by believers (esp. in pre-modern or less formalised religions).

All these three above mentioned essential components of any religion are strongly rooted in culture, social structure, political environment, and economic conditions, and do not come as something genuinely novel. ${ }^{6}$ However, they would not allow us to draw a clear line of distinction between religious outlooks

\footnotetext{
${ }^{4}$ Balcerowicz (2009).

5 In the definition proposed below, I rely on Balcerowicz (2009) where a number of alternative approaches to define religion are discussed.

6 These elements are to various degrees discernible in some earlier, classical definitions of religion, e.g. in Durkheim (1912: livre 1, I § 3), Malinowski (1911-1913: 67), Frazer (1925: 50), van der Leeuw (1933: esp. §§ 48-92), Wach (1944: 19-34, Chpt. II passim), Lienhardt (1956: 322), or in Glock and Stark (1965: 20-38) distinguish five aspects: experiential, ideo-logical, ritualistic, intellectual, and consequential.
} 
proper and certain other world views which do not themselves purport to be, or are generally not regarded, as religions, for instance certain totalitarian political doctrines which were indentified in history as 'political religions', such as communism in Stalinist Soviet Union ${ }^{7}$ or Nazism in the Third Reich ('German Religion'), ${ }^{8}$ in the case of which one may indeed distinguish their respective doctrines, cults and communities. For this reason, there is still a need to introduce one more defining component of religion per se, which is:

4. Irrationality, or essentially irrational character of religion, being expressed in the believers' consent to some kind of tacit incoherence of their belief system. Four layers can be distinguished within the complex of irrationality so understood. The first of them, 'incomplete responsibility', is the believers' consent to partially entrust the responsibility for their fate to certain transcendent agents or supernatural factors (God, karman, destiny, etc.). The second layer, 'unquestionability of norms', concerns the unquestioned admittance on the part of believers of a set of pre-existing, ready-tailored norms that comprise explicatory and moral rules, and these rules are never seriously called in question. Irrationality's third layer, 'uncriticality', is an articulation of the believers' lack of readiness to critically approach the essence of their religious experience, which entails first the unwillingness to critically assess the contents of the religious experience as such and to critically question its rudiments and nature (e.g. physical, physiological etc.), and second, the lack of genuine readiness to abandon the set of beliefs once their critical examination would favour a contrary hypothesis. To examine 'critically', or a critical approach, consists in an equal treatment of the alternatives $b \vee b$, where $b$ stands for [the validity of] a particular religious belief, or perhaps more precisely, the validity of the interpretation of a particular experience as an expression of forces or phenomena considered to be strictly of religious character, not cause by natural or physical forces. Consequently, any examination of the religious experience has to be 'tilted' towards an interpretation which is necessarily within the explanatory framework of a particular religious doctrine.

The fourth layer, 'essential unknowability', is a conscious abandonment of the desire to cognise limitlessly. The essence of the religious experience, say 'the experience of the sacred', sets clear limits both on the range of what can potentially be known and on human cognitive faculties, and thereby introduces a sphere of reality which is and will for ever remain unknowable both in its nature and to the human mind. Self-imposed limits as a result of the acceptance of such essential unknowability do not concern the nature of our faculties as such, which are admittedly restricted in their capacities, but result from an accepted set of dogmas. Allowing for a sphere of reality which is taken to be unknowable essentially, not merely due to the limitedness of our faculties,

\footnotetext{
7 Cf. the assessment of Russell (1920: 113-114): "By a religion I mean a set of beliefs held as dogmas, dominating the conduct of life, going beyond or contrary to evidence, and inculcated by methods which are emotional or authoritarian, not intellectual. By this definition, Bolshevism is a religion... Among religions, Bolshevism is to be reckoned with Mohammedanism rather than with Christianity and Buddhism".

${ }^{8}$ Kolnai (1988: 84, 89, 107, 148), Goodrick-Clarke (2004: vii).
} 
happens a priori, and is not preceded by some kind of purely rational analysis, but is based on faith or religious experience. This point is quite different from another question whether limits to our knowledge exist or not and to the (un)knowability thesis, whether in its Western ${ }^{9}$ or Indian formulations, ${ }^{10}$ or any other. This is also different from the question whether we can construct a complete model of knowledge (Gödel's incompleteness theorems). Similarly, we should distinguish irrationality as a structural feature of any religious belief system from the actual psychological aspect of our minds: each of us, whether religious nor not, happens to be and act irrationally.

The fourth essential component of any religious belief system, namely irrationality, may seem controversial, therefore the remaining part of the paper will elaborate on this point, and in doing so the mode of applying logic will be essential.

Every religion, with no exception, will apply certain inferences and reasoning at least occasionally and to some limited degree, even when it happens to claim that there is an incommensurable gap between ratio and fides, and logic and reason can serve no salvific purpose. Yet also in such cases we can speak of a partial application of logic to certain spheres of religion and its doctrine or cult (which is rooted in or explained as expressive of the doctrine), including the hierarchy, which is necessitated by the need to make certain dogmas and religious beliefs intelligible and communicable. Even a claim rejecting the applicability and usefulness of reason will also require resorting to logic, inference and argument. The recourse to reasoning and logic is also a requirement of any debate, primarily in three following cases: (1) when certain doubts of a religious person arise as to the nature of certain beliefs, and the task of reason is to make faith more intelligible, and in the case of two kinds of the communication with non-religionists, i.e. (2) in the case of missionary activities and (3) in the case of defence of one's own religion against a criticism levelled from representatives of other religions or world-views.

Further, some religions, or certain branches within a particular religion, explicitly admit logic and reasoning as an important tool for the inquiry into ultimate truths, and an auxiliary to the proper interpretation of revelation (e.g. textual analysis, hermeneutics, etc.).

It is therefore not the case that no aspects of a religious belief system are rational, and based on logic, for some definitely are. I will call such an aspect of a religion where logic and reasoning are applied either declaratively or practically (albeit not formally admitted) a 'rationalized' religion. Figure 1 represents such a religion in its rational aspect, such as theology, non-mystical experience, exegetical commentary on a dogmatic issue etc.

We can distinguish three constituent segments within a religious belief system. The first is the body of dogmas, i.e. most basic, permanent and indisputable principal

\footnotetext{
${ }^{9}$ Such as Fitch's Paradox of Knowability, Fitch (1963), Theorem 5-"If there is some true proposition which nobody knows (or has known or will know) to be true, then there is a true proposition which nobody can know to be true." See also Rescher (1984: $150 \mathrm{ff}$.).

${ }^{10}$ Universal knowability thesis of the Indian schools of logic and nature (Nyāya-Vaiśeșika), see, e.g. Perrett (1999) and Balcerowicz (2010).
} 
Fig. 1 General structure: religion in its rational aspect

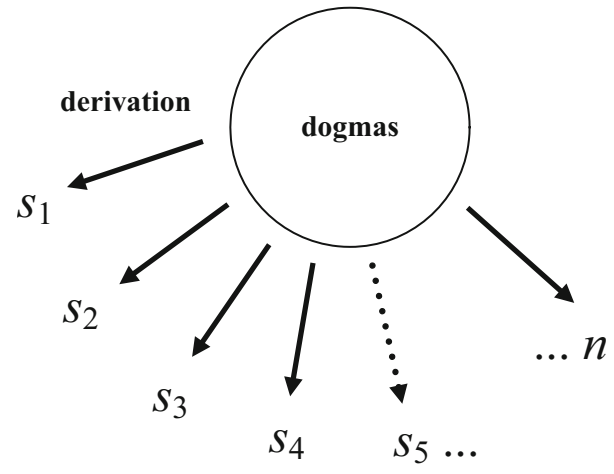

beliefs, moral valuations etc.

beliefs, which are fundamental to the system. The dogmas (either formally codified or held in a unsystematized way) are essential to any religious system in two ways. First, they form a doctrinal basis of a particular religious tradition, and second, they make it distinct from other religions. For instance, such a set of core beliefs for Christians would be monotheism (irrespective of the admission of the doctrine of the Trinity or its rejection), the person of Jesus Christ (irrespective of whether he is understood to in a divine or a human form, or a combination of both) etc.; for the Buddhists, these are the four noble truths and the eightfold path leading to liberation, etc., the six articles of faith for Muslims, etc. Every offshoot or subsect of a wider religion, say, the Catholics or Jehovah's Witnesses, the Theravādins or the Madhyāmikas, will hold more particularized dogmas which distinguish them from other branches historically and 'genetically' affiliated within the same main religious tradition. Left uninterpreted, the dogmas are ambiguous, sometimes to the extent of incomprehensibility. They always stand in need of some elucidation or elaboration. Clearly, we speak here of dogmas as most basic eidetic elements within a religious tradition, not as nominal dogmas, or articles of faith called 'dogmas', and codified as such for instance in the Catholic Church or Sunni Islam. Which doctrinal statements within a particular religion are classified as dogmas in this sense is always relative to that particular tradition. It is primarily the religious leaders or the elite who decide which statements are most fundamental and irreducible.

The second constituent segment of a religion in its rational aspect incorporates derivation strategies, such as logical principles (rules of derivation), hermeneutical methods or exegetical techniques (which do not necessarily have to strictly rely on logic). These are, in general, various methodologies to interpret the body of dogmas, to derive particular judgements from them that can be applied to practical situations or metaphysical questions etc., to explain away apparent inconsistencies and points rising doubts, to provide some meaningful elucidation of the revelation or of the initial teaching of its founders (provided such a religion is based on some kind of 'revelation'). This element is crucial because it allows either to integrate certain other convictions or practices, historically or essentially external to core beliefs, within the fabric of faith, or to develop a dogma into a concrete meaningful image. 
An example of the first case is a range of beliefs surrounding the tradition of Christmas and the choice of 25th December as its date, through which earlier solar traditions came to be embedded within Christian tradition. An example of the second case is the hermeneutical strategy explaining the idea of monotheism as resting on the concept of the sole and ultimately good being Ahura Mazda within a dualistic system, quite different from another interpretative strategy leading to the acceptance of three consubstantial persons (the Trinity) by the Roman Catholic Church. In fact, a dogma can hardly exist uninterpreted. Often divergent derivation strategies can be distinguished even within one and the same religious tradition, for instance ijtihâd (independent reasoning) and taqlìd (conformity to legal precedent). The choice of particular methods is specific to individual religious traditions, but most of these methods rely on reasoning and on certain inference rules provided by logic.

The third constituent segment of a 'rationalized' religion is made of a potentially infinite set of secondary beliefs, moral valuations, religious legal decrees, particular solutions to moral questions etc., which are either derived from the dogmas or somehow harmonized with them. In other words, the body of dogmas either entails its implications both in religious theory (theology, cosmogony, salvific doctrine etc.) and in religious practice or orthopraxy (good-bad moral valuations, auspiciousinauspicious deeds, or karman etc.) or serves as a benchmark bestowing validity on various particularized beliefs. Various exegetical approaches extend the set of doctrinal statements and practices which make up orthodoxy and orthopraxy, and provide for an underlying meaning of the group structure. In fact, both orthopraxy and communal structure can be translated into concrete statements, either descriptive or prescriptive. Changing circumstances may lead to an expansion of such secondary statements which is a result of the need to integrate new practices, legal or moral valuations or even a new understanding of the physical world within the traditional framework of other secondary beliefs or practices. A good example is a recent ruling of the Congregation for Divine Worship and the Discipline of the Sacraments in Vatican that "hosts that are completely gluten-free are invalid matter for the celebration of the Eucharist." "Such an extension of a system of beliefs is clearly a response to a new situation created by the development of science and medicine which has changed social awareness to the effect that certain disorders are gluten-related.

Strikingly, the structure of such a 'rationalized' religious belief system resembles, but is in no way identical with, systems of logic or other formal systems, such as sciences, which fall into the broad category of non-religious belief systems. Clearly, not every non-religious belief system is based on logic and reasoning and is not meant to consistent or axiomatic, but some certainly are. While dealing with the question of logic in religious and non-religious belief systems, I will be concerned only with such non-religious belief systems which are modelled in a manner that is meant to make them consistent and which rest on strong foundations of logic.

${ }^{11}$ CDWDS (2017). 
Fig. 2 General structure: logic and other formal systems

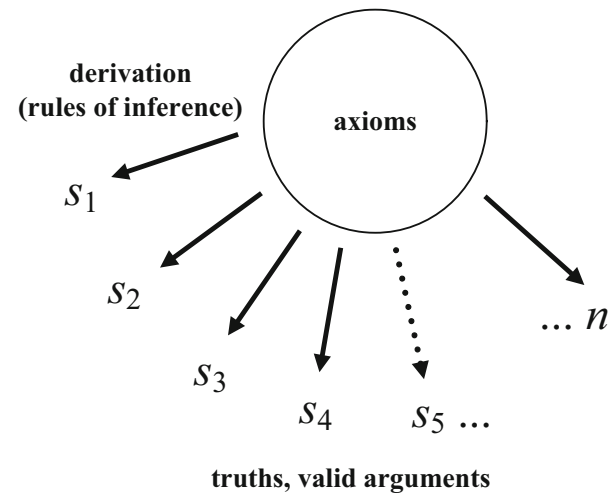

In its structure, most broadly speaking, logic (and the foregoing is not an attempt at a definition) concerns the study of general laws of reasoning used in valid arguments which involve axioms and rules of inference (derivation rules) applied in deriving truths, or valid statements through valid arguments, as depicted in Fig. 2. Broadly speaking, the same model will also accurately represent other rationally developed systems of knowledge which purport to be largely consistent, such as scientific theory, or a system of philosophy.

We can observe certain obvious similarities between 'rationalized' religion, or rather religion in its rationalized aspect (Fig. 1), and formal non-religious systems, including a system of logic or a scientific theory (Fig. 2). Such structural similarities are shown in Fig. 3.

Such similarities, or even partial structural overlap, no doubt allow for the use of logic and logical tools in religion as such, which makes some aspects of religious systems undeniably rational. Accordingly, in many ways a religious system may share a number of features with certain non-religious belief systems, e.g. a system of logic per se or a scientific theory. An analysis of such similarities concerning logic and of the degree of the partial overlap will be pivotal in demonstrating certain important structural differences between religious and non-religious belief systems.

In its structure, any such theory $T$, whether it 'encapsulates' religious beliefs or formalizes scientific models and other consistent non-religious systems, ${ }^{12}$ but also a system of logic, will consist of a finite set of primary statements or primitive notions ('values', i.e. dogmas or axioms) $|P|=\left\{\mathrm{p}_{1}, \mathrm{p}_{2}, \mathrm{p}_{3}, \mathrm{p}_{4}, \ldots \mathrm{p}_{\mathrm{n}}\right\}$, finite set of rules of derivations $|R|=\left\{\mathrm{r}_{1}, \mathrm{r}_{2}, \mathrm{r}_{3}, \mathrm{r}_{4}, \ldots \mathrm{r}_{\mathrm{n}}\right\}$, and an infinite set of derived secondary statements $|S|=\left\{\mathrm{s}_{1}, \mathrm{~s}_{2}, \mathrm{~s}_{3}, \mathrm{~s}_{4}, \ldots\right\}$.

Clearly, primary statements (dogmas or axioms) $\in|P|$ serve as premises from which secondary statements $\in|S|$ are derived as logical consequences with the help

\footnotetext{
12 By the expression 'consistent non-religious systems', I mean logic-based and rationally developed systems, including axiomatic systems and empirical theories, which are constructed or developed with the aim to be eventually consistent, and in which inconsistencies, once they come to the surface, are intended to be ultimately eliminated. Of course, not every non-religious system has to be fully consistent, rational and based on logic.
} 
Fig. 3 Structural similarities between religion (in its 'rationalized' aspect) and logic and other formal systems

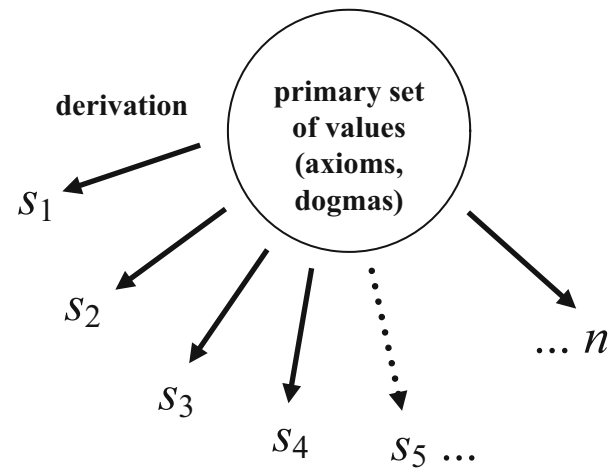

derived, secondary statements

(truths, beliefs)

of rules of inference $\in|R|$. Such derived secondary statements may further serve as premises, lemmata etc., to derive additional secondary statements.

However, a closer analysis will reveal certain basic structural differences between the use of logic in a religious system (religion) and in certain other consistent non-religious systems, such as a scientific theory, algebra, geometry, a system of logic, a system of philosophy. To illustrate this point, some conspicuous differences will emerge when we take a closer look at the process of resolving certain derived contradictions and inconsistencies in situations whey they are observed. It may happen that one derives a contradiction $s_{4} \wedge s_{4}$ from a set of primary statements or primitive notions, whether dogmas in a religious system or axioms in a non-religious theory, as illustrated in Fig. 4.

That inconsistencies and apparent contradictions arise once one derives secondary statements, either religious beliefs/moral valuations or truths/valid arguments, from primary statements, either dogmas or axioms, in religious and nonreligious systems, respectively, including logical (purely theoretical) and empirical (e.g. scientific) theories, is a frequent phenomenon, and it is even expected.

The result is either certain inconsistencies or outright contradictions between two secondary statements derived from the primary statements. In other words, in the infinite set of derived secondary statements $|S|=\left\{s_{1}, s_{2}, s_{3}, s_{4}, \ldots\right\}$, we may occasionally encounter two statements of such nature, e.g. $s_{4} \wedge s_{4}$, or a similar inconsistency situation: $\left(\mathrm{s}_{3} \rightarrow \mathrm{s}_{5}\right) \wedge\left(\mathrm{s}_{4} \rightarrow \mathrm{s}_{5}\right)$, etc. Generally, a common strategy adopted in such situations is what I would call, using the terminology derived from the counterpoint and fugue technique, diminution and augmentation. As 'diminution', I understand a situation when the theory is revised by the removal-from the set of secondary statements $|S|=\left\{s_{1}, s_{2}, s_{3}, s_{4}, s_{5}, s_{5}, \ldots\right\}$ - one of such contradictory statements, say $s_{5}$, with the result: $|S|=\left\{s_{1}, s_{2}, s_{3}, s_{4}, s_{5}, \ldots\right\}$. In nonreligious systems, that is primarily in a particular scientific theory, but of course not only, it is an obvious procedure to drop theses which have been proven wrong or inconsistent with other statements of the theory, or have been disqualified for 
whatever reason, e.g. "The Earth is flat" or "If toward each of the points of a given sphere there tend equal centripetal forces decreasing in the squared ratio of the distances from the points, I say that this sphere will attract any other homogeneous sphere with a force inversely proportional to the square of the distance between the centres," 13 known as Newton's law of universal gravitation, superseded by Einstein's theory of general relativity. The same strategy is also used in religious belief systems. For instance, the idea that the Buddha and his disciple, i.e. "Barlaam and Josaphat are celebrated in the Catholic Church as Christian saints and martyrs on 27th November," was still present at the early twentieth century in The Roman Martyrology, ${ }^{14}$ however both martyrs-saints were removed from its new revised edition of $2001 .^{15}$

Augmentation is a process when the set of secondary statements $|S|=\left\{\mathrm{s}_{1}, \mathrm{~s}_{2}, \mathrm{~s}_{3}, \ldots, \mathrm{s}_{\mathrm{n}}\right.$, ... \} of theory $T$ is amended, or improved, with statements, such as $s_{n+1}$ etc., not present in its earlier version: $|S|=\left\{\mathrm{s}_{1}, \mathrm{~s}_{2}, \mathrm{~s}_{3}, \ldots, \mathrm{s}_{\mathrm{n}}, \mathrm{s}_{\mathbf{n}+\mathbf{1}}, \ldots\right\}$. Obviously, the progress in any scientific theory or any other system of knowledge is based on such augmentation, that is on the introduction of new theorems, or statements derived from premises and empirical observation and possible to new discoveries. Similarly, also a system of logic can be expanded through the augmentation of new lemmata and propositions. This is also a standard process in any religion, observable for instance in cases when certain beliefs are adopted to a new situation under changing historical, social, political or economic conditions, e.g. $s_{n}+1=$ "the burkini is a proper dress for a Muslim women on a beach" in Islam, which marks the social change concerning the Islamic women's dress and lifestyle adopted to new requirements, or "in some cases the divorced-and-remarried may receive the Eucharist without the need to change their way of life" ${ }^{16}$ in the Catholic Church. Clearly, such a process to adapt to new circumstances and to respond to the changing needs of its believers is also indispensable for any religion to survive, which has to be adapted to new circumstances.

Diminution and augmentation can operate simultaneously. A case when one statement is amended, or improved, within a set of secondary statements $|S|=\left\{\mathrm{s}_{1}\right.$, $\left.s_{2}, s_{3}, \ldots, s_{\mathbf{p}}, \ldots\right\}$ is a such combination of two processes applied jointly. The diminution removes faulty $\mathrm{s}_{\mathrm{p}}$ and augmentation replaces it with what seems correct $\mathrm{s}_{\mathrm{q}}$, with the result: $|S|=\left\{\mathrm{s}_{1}, \mathrm{~s}_{2}, \mathrm{~s}_{3}, \ldots, \mathrm{s}_{\mathbf{q}}, \ldots\right\}$. Within a religious system, say the Orthodox Church of Greece, the idea expressed through the statement "a woman is not entitled to the diaconate", i.e. the standard view in Eastern Churches since the early mediaeval times that the office of the deaconess is not permitted, was amended to "a woman can be appointed (but not ordained as) a deacon" by the Holy Synod of the Orthodox Church of Greece on 9th October 2004. ${ }^{17}$ Analogously, within a non-

\footnotetext{
13 Proposition 75, Theorem 35, in Newton (1999: 956).

14 "In India, on the confines of Persia, the Saints Barlaam and Josaphat['s] wonderful deeds were written by St. John Damascene"/“Apud Indos, Persis finitimos, sanctorum Barlaam et Josaphat, quorum actus mirandos sanctus Joannes Damascenus conscripsit,” RM (1913: 486).

15 RM (2001).

16 "The baptized who are divorced and civilly remarried need to be more fully integrated into Christian communities in the variety of ways possible," AL (2016: 229).

17 See Zagano (2005), Macy (2007: 17), McGuckin (2008: 327).
} 
Fig. 4 A contradiction in religious and non-religious systems

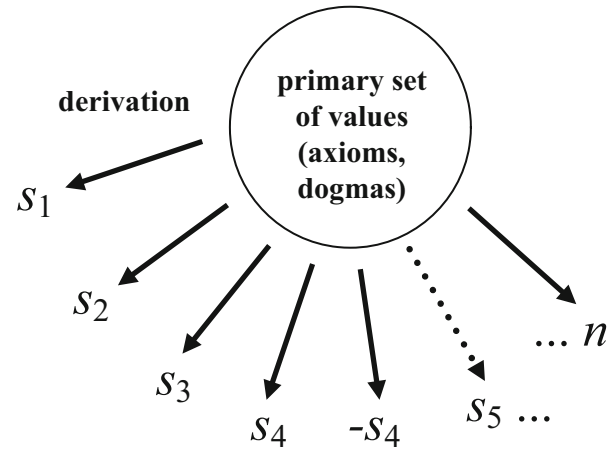

derived, secondary statements (truths, beliefs)

religious system, "gravity is a force" (Newton) will be replaced with, or technically speaking removed and a new statement introduced in its place: "gravity is a consequence of the space-time curvature" (Einstein). Through a method combining both diminution and augmentation, the body of secondary statements forming a theory is expanded, inconsistencies, incompatibilities and contradictions eliminated or, very often, tolerated and (temporarily) accepted, until they are somehow resolved. With respect to the admission of inconsistencies, the difference between religious and non-religious systems is primarily quantitative, not qualitative, at this level. To encounter inconsistencies in religion is commonplace, but also consistent non-religious systems, such science, tolerate discrepancies, inconsistencies and contradictions until a new extended explanatory theory is established.

And here lies, I argue, the key to determine a qualitative difference between religious and non-religious belief systems, namely within the modifiability, or adaptability, of primary statements of a system. A useful model to describe certain important structural differences is the distinction into two levels of rationality: ${ }^{18}$ first- and second-level rationalities (Fig. 5). So far we have dealt with the first-level rationality, leaving the second-level rationality intact for the time being.

Within the first-level rationality, actual judgements and opinions which are modified through diminution and augmentation in order to resolve inconsistencies and remove contradictions fall exclusively in the category of secondary statements, derivable from the primary set of statements, either dogmas (religious system) or axioms (non-religious system). In other words, the first-level rationality is about how one derives and adjusts one's beliefs on the basis of a set of values and primitive notions which are taken for granted and which stand in no need of further justification. At this level of rationality, the primary set of statements remains intact and unquestionable, beyond any attempt to verify the validity of its elements. All attempts to remove inconsistencies and contradictions occurring within the system are made with respect to derivation rules and secondary statements alone. At best,

\footnotetext{
18 See Balcerowicz (2011). The idea was first developed in my paper "Rationality as a Common Public Domain" delivered at the International Conference "Dialogue Among Civilisations", Warsaw 25 April 2003.
} 
inconsistencies and contradictions are tolerated for as long as it is feasible within non-religious systems. In religious systems, however, such consistencies and contradictions are often explicitly acknowledged and accepted under various schemes, such as 'mystery', 'the gap between reason and faith', 'divine plan', 'paradox', 'god's game' (līlā), 'the true nature of nirvāna' etc. The justification for the derived secondary statements, i.e. for the ordinary beliefs and actions expressive of such beliefs, is principally their concurrence with and derivability from the set of primary set of primary, or dogmas. If a particular belief or action appears to be in conflict with it, it should rather be abandoned, revised, adjusted in order to bring it into conformity with the dogmatic core or simply acknowledged as such, without questioning the fundaments of the dogmas. And this is precisely what most religious people do or profess to do. Similarly in consistent non-religious systems, say in the Standard Model of particle physics, the Minimal Supersymmetric Standard Model had to be eventually abandoned after no evidence for such supersymmetry was found through the experiments using the Large Hadron Collider between 2010 and 2013, and instead the existence of Higgs boson was confirmed in the experiments. The adjustment did not require the rejection of the fundaments of the Standard Model, serving as a kind of primitive notions. As long as inconsistencies or conflicting explanatory scenarios can be resolved or tolerated and the complex network of beliefs remains largely congruous, without causing serious problems that would critically shake up the system, the system of beliefs is modified at the first level of secondary statements. And, as I have mentioned earlier, at this level of rationality, the difference between the approach to contradictions and incongruity as presented within religious and non-religious systems is basically quantitative.

The second-level rationality, which functions as a meta-level required for the first-level rationality, presents quite a different picture. Primary set of beliefs is treated as open to modifications and adjustments under very particular, stringent conditions, namely once it is observed that contradictions between secondary statements derived from the set of primary statements, or ensuing inconsistencies within the theory, cannot be successfully resolved, given all rules of derivation have been positively verified, demonstrated as not subject to sublation and proven correct. In such rare cases, when irresolvable contradictions combine to a "critical mass', one progresses towards the verification and assessment of the validity of the

Fig. 5 Two levels of rationality: first and second level

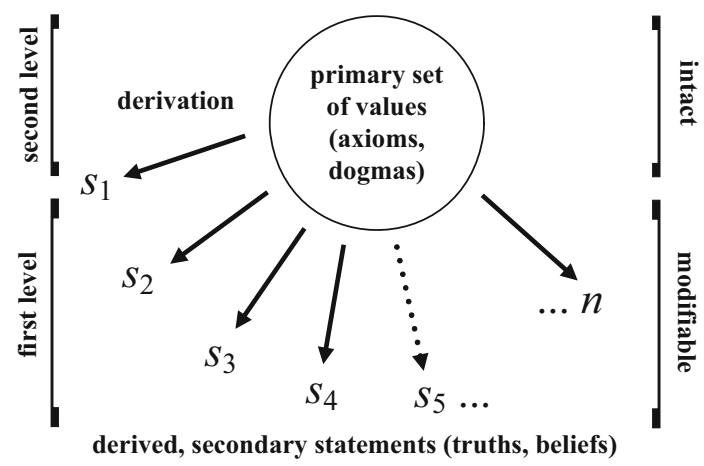

derived, secondary statements (truths, beliefs) 
Fig. 6 Second-level rationality

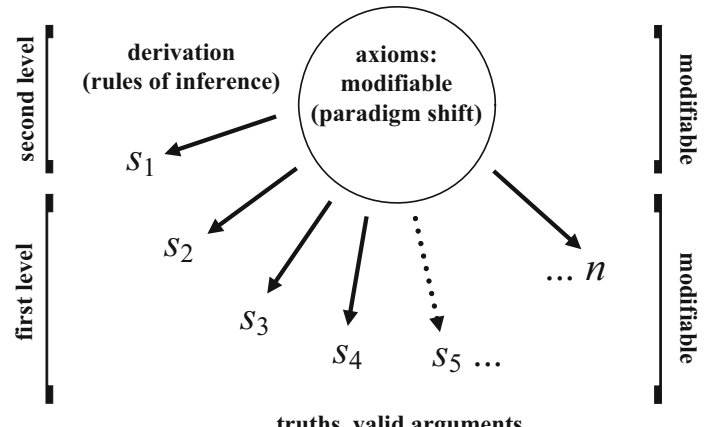

Fig. 7 First-level rationality in religious belief systems

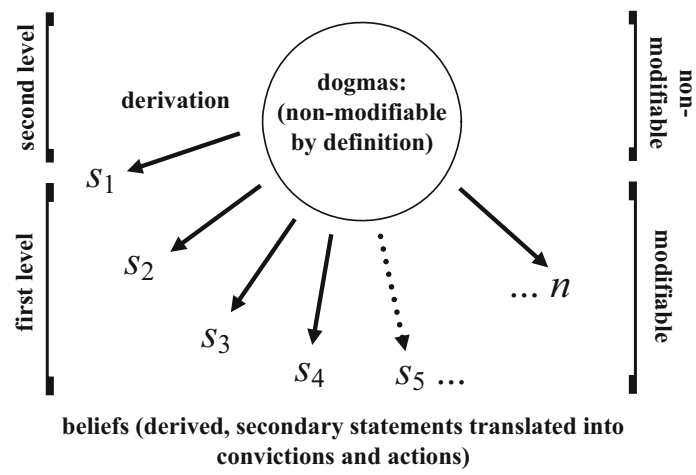

set of primary statements (axioms). This is the only stage, or level of rationality, which allows for a true choice of primary set of beliefs. The second-level rationality retains all conditions of first-level rationality, but in addition it presupposes two important elements, not present with the first-level rationality: (1) a conscious and rational decision to amend the axiomatic, primary set of statements for certain rationally justifiable reasons, and (2) the readiness to question the validity of the axioms and to modify them if a critical enquiry necessitates that. If contradictions between secondary statements (which include also rules and actions translated into secondary statements) and inconsistencies within a system are uncovered to a degree which cannot be successfully resolved through modifications and amendments of the derived secondary statements, one is required to look for the source of such inconsistencies within the set of primary statements. This step, however, is tantamount to the readiness to resort to questioning the fundaments of the system resting on the set of primary statements. As a result, the set of primary statements can no longer be taken as permanently fixed, unmodifiable and intact. Second-level rationality stipulates that the validity, consistency and soundness of all statements of the system are potentially open to questioning: what can be critically examined, readjusted and modified is not only derived secondary statements, and this is what is 
usually done, but also the primary statements. In other words, the modifiability and adjustability of beliefs is imperative at both levels, as in Fig. 6.

Such a second-level rationality can, but does not necessarily have to, be represented in non-religious systems alone, and is not possible with religious belief systems, based on faith. It is only in consistent non-religious systems that axioms or primitive notions are liable to occasional modifications and readjustments with the purpose to eliminate certain observed inconsistencies between derived secondary statements (knowledge about reality) and in accordance with observable facts so that the whole theory corresponds to the reality the way it is perceived. The remodelling of the set of primary beliefs in a system is rare and should be treated as a last-resort solution to eliminate detectable contradictions between derived secondary statements which can no longer be reconciled. In the history of science, such threshold situations are called a paradigm shift (Thomas Kuhn, The Structure of Scientific Revolutions), when a 'critical mass' of incongruities, combined with an emerging new explanatory theory, enforces the change within the set of primary statements. This is precisely what happens at the stage of the second-level rationality. In religious systems, the set of primary statements, i.e. dogmas, remains structurally intact and continues as non-modifiable by definition, as in Fig. 7.

No application of logic and force of reasoning can compel one to embark on such a dogmatic readjustment in a religious system. A change within the body of dogmas, i.e. the set of the primary statements, would result either in renouncing the religious outlook per se (if the transformation is extensive enough) or in an abandonment of a particular religion either at a personal or communal level. In the first case, this results in the person's individual conversion, or embracing another religion, while retaining the basic structure of one's own beliefs, and in the second case, this leads to a historical transformation of, say, Judaism into Christianity or Islam and to branching into sects and subsects. We could call such cases when a new religious tradition emerges out of a pre-existing one a kind of 'paradigm shift', but only metaphorically. In a monotheistic religion, for instance, one cannot seriously question the existence of god, indicating one's genuine readiness to accept god's non-existence logically on par with god's existence (as an equally valid alternative), while remaining an altogether religious believer who wishes to stay in agreement with the monotheistic dogmas of his or her religion. To do so would amount to apostasy, at least in the sense of criticism—be it tentative and temporal — of the doctrinal fundaments of one's own religion. A Muslim who happens to entertain sincere doubts concerning the existence of Allah is straightforwardly considered an apostate. We should here clearly distinguish a genuine doubt from a methodological 'doubt' as an heuristic device used to strengthen one's own faith when one tentatively contemplates certain alternatives only in order to ultimately defeat them. The latter is well exemplified by the protagonist of the Book of Job who at a point comes to question the very idea of a just god. Descartes' doubt about omnipotent god is definitely not a case of a genuine scepticism, but rather a method to ultimately re-confirm the existence of god and his omnipotence. The second-level rationality however requires that one is admittedly able to conceive of a theoretical possibility that the set of primary beliefs may be proven wrong and may have to be readjusted and corrected by replacing an original belief, say "god exists", with its 
contradiction, "god does not exist". However, such a step is not available to a believer without undermining his or her believer's status: once a believer in god begins to contemplate the opposite thesis, one immediately becomes an agnostic, disbeliever or apostate. This closes an option of a paradigm shift within any religious belief systems: the dogmas are simply not modifiable.

In addition, what remains markedly different in the case of a non-religious paradigm shift, as distinguished from a religious metaphorical 'paradigm shift', is the application of derivation rules. In a non-religious system, the paradigm shift results from an attempt to preserve logical consistency of the system and from deployment of reasoning and logic-based arguments; the derivation rules are those of logic, and the emerging system is merely an extension of the former, and is unquestionably treated as such. In science, Einstein's physics is not considered a completely new system as compared to Newtonian physics, which is treated as a certain approximation of the former in certain physical conditions. In contradistinction to that, in a religious system, a 'paradigm shift' is never caused by observable inconsistencies of logical nature within the system and by inferences, but rather a result of extra-logical factors of spiritual, social, psychological, political etc. nature, subsumed for instance under an idea of a divine revelation or something similar. The paradoxes and illogicalities of the k-ōan will not bring an adept of Zen Buddhism to abandon the religious practice. Logical and moral paradoxes concerning an omniscient, omnipotent and benevolent god vis-à-vis the problem of theodicy or a number of omnipotence paradoxes, such as the paradox of the stone, irrespective of how irresolvable they may seem, will not persuade a Muslim or Christian to abandon their faiths. On the contrary, they will rather strengthen religious committal and zeal, and if they are given due consideration it is meant to intensify the spiritual progress. Further, anything that would correspond to a paradigm shift within a religion would be considered either a case of apostasy, blasphemy, conversion to another religion or complete renouncement the religious world-view.

To put it differently, the development of the set of primary sentences, including a radical change within it, is not only embedded in a consistent non-religious system, but even awaited and envisaged. It is a natural feature of its expandability. In contradistinction to it, such a development is not conceivable within religious systems which declare to preserve the original doctrine of their founders or forefathers, of god, of prophets or of the tradition. Such a declaration should, of course, not be confused with the actual propensity of all religious systems to evolve, metamorphose and adapt to new social, political and economic conditions, lest they face the risk of gradual disappearance and demise.

We can therefore conclude that, despite an oft repeated claim that faith-based religions and reason-anchored scientific or philosophical world-views are ultimately similar, the structural differences between religious and non-religious belief systems are clearly determinable and concern the treatment of the primary set of values (axioms, dogmas etc.), i.e. their modifiability and extendibility.

The first-level rationality can be frequently seen at work within most religious belief systems and is necessarily operative within any consistent non-religious system at the level of derived secondary statements, subsidiary beliefs or 
demonstrated truths respectively. This is the stage where religion and a consistent non-religious theory, e.g. scientific theory, differ merely qualitatively, i.e. in the degree in which logic and reason are exercised in order to bring the consistency of secondary statements derived from the set of primary statements or primitive notions (dogmas, axioms etc.).

However, it is only the second-level rationality that entails the readiness to change the set of primary statements, i.e. axioms, and is observable in consistent non-religious systems alone, such as axiomatic systems, science etc., whereas it is by definition absent in all religious belief systems which do not allow for any formally acknowledged transformation of the body of dogmas solely on the basis of inconsistencies demonstrated by logic and argument. Such a significant change within the set of primary statements that is characteristic of the second-level rationality can be termed a paradigm shift. Accordingly, the second-level rationality marks a crucial structural and qualitative difference between religious and nonreligious systems. And this is a stage where the essence of religion and the nature a consistent non-religious belief system significantly diverge. Furthermore, the actual forces that bring about a change within the adopted set of primary statements (axioms) is eventually prompted by the application of reasoning and argument based on logic, principally with reference to observed facts. In this way, logic provides the proper rules of derivation and remains the main criterion for rationality.

Open Access This article is distributed under the terms of the Creative Commons Attribution 4.0 International License (http://creativecommons.org/licenses/by/4.0/), which permits unrestricted use, distribution, and reproduction in any medium, provided you give appropriate credit to the original author(s) and the source, provide a link to the Creative Commons license, and indicate if changes were made.

\section{References}

AL. (2016). Post-synodal apostolic exhortation Amoris Laetitia of the holy father francis to bishops, priests and deacons, consecrated persons, christian married couples, and all the lay faithful on love in the family. Vatican City: Libreria Editrice Vaticana.

Balcerowicz, P. (2009). In M. Modi (Ed.), Jainism and the definition of religion. Mumbai: Hindi Granth Karyalay. http://www.balcerowicz.eu/indology/Jainism_and_the_Definition_of_Religion.pdf. Accessed 15 June 2017.

Balcerowicz, P. (2010). What exists for the Vaiśeșika? In P. Balcerowicz (Ed.), Logic and belief in Indian philosophy (pp. 241-348). Delhi: Motilal Banarsidass.

Balcerowicz, P. (2011). Rationality as a common public domain. Dialogue and Universalism, 1, 73-94.

CDWDS. (2017). Congregation for Divine Worship and the Discipline of the Sacraments: "Circular letter to Bishops on the bread and wine for the Eucharist," Prot. N. 320/17, 15 June 2017, Vatican. http:// www.vatican.va/roman_curia/congregations/ccdds/documents/rc_con_ccdds_doc_20170615_ lettera-su-pane-vino-eucaristia_en.html. Accessed 15 June 2017.

Durkheim, É. (1912). Les formes élémentaires de la vie religieuse. Le système totémique en Australie. Paris: Alcan (English translation: The elementary forms of the religious life. J. S. Swain, Trans. London: George Allen \& Unwin, 1915).

Eliade, M. (1949). Traité d'histoire des religions. Paris: Payot.

Fitch, F. B. (1963). A logical analysis of some value concepts. The Journal of Symbolic Logic, 28(2), 135142.

Frazer, J. G. (1925). The golden bough. A study in magic and religion (Abridged ed., Vol. 1). New York: The Macmillan Company.

Glock, C. Y., \& Stark, R. (1965). Religion and society in tension. Chicago: Rand McNally \& Co. 
Goodrick-Clarke, N. (2004). The occult roots of nazism: Secret aryan cults and their influence on nazi ideology. New York: I.B. Tauris \& Co Ltd. (First edition: 1985).

Kołakowski, L. (1982). Religion-If there is no God.... Glasgow: Fontana Paperbacks/Oxford University Press.

Kolnai, A. (1988). The war against the west. New York: The Viking Press (First edition: 1938).

Lienhardt, R. G. (1956). Religion. In H. L. Shapiro (Ed.), Man, culture and society (pp. 310-344). New York: Oxford University Press.

Macy, G. (2007). The hidden history of women's ordination: Female clergy in the medieval West. Oxford: Oxford University Press.

Malinowski, B. (1911-1913). Totemizm i egzogamia (Totemism and exogamy-A reply to J. G. Frazer, Published in Polish), Lud 17(2), 31-56; 18, 14-57; 19, 153-171. [Reprinted: Dzieła (Collected Works), Vol. 7, Warszawa: PWN, 1990: 13-106; English translation: R. J. Thornton, P. Skalník, L. dwik Krzyżanowski (eds.): The early writings of Bronislaw Malinowski. Cambridge: Cambridge University Press, 1993, pp. 123-200].

McGuckin, J. A. (2008). The Orthodox Church. An introduction to its history, doctrine, and spiritual culture. Malden: Blackwell Publishing.

Newton, I. (1999). The principia: Mathematical principles of natural philosophy. A New Translation by I. Bernard Cohen and Anne Whitman, Preceded by A Guide to Newton's Principia, by I. Bernard Cohen. Berkeley: University of California Press.

Otto, R. (1926). The idea of the holy (J. W. Harvey, Trans.). London: Oxford University Press (Humphrey Milford) (German original edition: Das Heilige: Über das irrationale in der Idee des Göttlichen und sein Verhältnis zum rationalen. München: C.H. Beck, 2004. First edition: 1917).

Perrett, R. W. (1999). Is whatever exists knowable and nameable? Philosophy East and West, 49(4), 401414.

Rescher, N. (1984). The limits of science. Berkeley (CA): University of California Press (Revised edition: Pittsburgh (PA): University of Pittsburgh Press, 1999).

RM. (1913). Martyrologium Romanum, gregorii XIII jussu editum Urbani VIII et Clementis X auctoritate recognitum...Eystadii. (English translation: The Roman Martyrology. Published by Order of Gregory XIII... Baltimore: John Murphy Company, 1916).

RM. (2001). Martyrologium Romanum: Editio Typica. Civitate Vaticana: Typis Vaticanis.

Russell, B. (1920). The practice and theory of bolshevism. London: George Allen \& Unwin Ltd. van der Leeuw, G. (1933). Phänomenologie der Religion. Tübingen: J.C.B. Mohr [Paul Siebeck].

Wach, J. (1944). Sociology of religion. Chicago: The University of Chicago Press.

Zagano, P. (2005). Grant her your spirit. America, The Jesuit Review, 192(4), 18-21. 